\title{
Stiffness and Strength of Granular Soils Improved by Biological Treatment Bacteria Microbial Cements
}

\author{
Mehdi Jalili ${ }^{a^{*}}$, Mohmad Reza Ghasemi ${ }^{\mathrm{b}}$, Ali Reza Pifloush ${ }^{\mathrm{c}}$ \\ ${ }^{a}$ PhD, Assistant Professor, Department of Civil Engineering, Technical \& Engineering Faculty, Semnan Branch, Islamic Azad University, \\ Semnan, Iran \\ ${ }^{b}$ PhD, Semnan Branch, Islamic Azad University, Semnan, Iran
}

${ }^{c}$ M.Sc. Graduated, Geotechnical Engineering, Department of Civil Engineering, Technical \& Engineering Faculty, Semnan Branch, Islamic Azad University, Semnan, Iran

\begin{abstract}
In some parts of the world mechanical properties of problematic soils are not suitable for construction purposes. Today, regard to the importance of the soil improvement; by considering methods with more concordance with the environmental mechanisms in the nature, and with study and combination of geotechnical science, microbiology and geochemistry; researchers try to provide a suitable way to improve the physical and mechanical properties of the problematic soils. In this paper, the effect of the aerobic microorganisms of Sporosarsina Pasteurii (PTCC 1645), as a producer of Urease for the sedimentation of calcium carbonate and improvement of granular soil of Garmsar Industrial Town is evaluated experimentally in order to check the effects of this phenomena on the shear strength and stiffness of the granular soils. The results of the uniaxial compressive strength tests show the effect of adding the above mentioned microbial solution to the soils, in case of increased uniaxial compressive strength and stiffness of the soil. It should be mentioned that the granular soils have no compressive strength, naturally but after bio cementation the samples got notable values.
\end{abstract}

\section{Keywords:}

Granular Soil;

Microbial Sediment;

Biological Cementation;

Compressive Strength;

Stiffness.

\section{Article History:}

Received: $07 \quad$ June 2018

Accepted: 19 August 2018

\section{1- Introduction}

In many parts of the world mechanical properties of problematic soils are not suitable for construction purposes. Generally some buildings, roads, railway, and etc. may need maintenance and rehabilitation because of the soil settlement or bearing capacity loss. Embankment and slopes may be unstable and beaches and rivers may be subjected to erosion. Earthquakes can also cause liquefaction of loose sediments and eventually will harm the structure that rest on or in the liquefiable soil. Although the reclamation projects in which it's main and important subject is densification of material, requires efficient and low-cost soil improvement methods. By population growth, needs to construction increased, and this important issue is not possible except with expansion of civil infrastructures. In addition the use of environmental compatible methods for soil improvement is very important. Microbial precipitated calcite (MICP) is a new method of soil improvement that using from bacteria to chemical process control and calcite deposits in the soil.

Through this enzymatic reaction, soil PH will increased and limestone crystal on the surface of particles and between cavities of soil will deposited and ultimately cause to connect the particles together and increase soil shear strength [1]. Urea hydrolysis by the enzyme urease, which is one of the easiest processes for the deposition of calcite in microbial sanitation projects are often taken advantages of this mechanism. In Equation (1) and (2) the formation process of calcite deposits in urea hydrolysis by the enzyme urease is provided [2].

$$
\mathrm{CO}\left(\mathrm{NH}_{2}\right)_{2}+2 \mathrm{H}_{2} \mathrm{O} \Rightarrow 2 \mathrm{NH}_{4}^{+}+\mathrm{CO}_{3}^{2-}
$$

\footnotetext{
*CONTACT: M.jalili@semnaniau.ac.ir

DOI: http://dx.doi.org/10.28991/esj-2018-01146

(C) This is an open access article under the CC-BY license (https://creativecommons.org/licenses/by/4.0/).
} 
$\mathrm{Ca}^{2+}+\mathrm{CO}_{3}^{2-} \Rightarrow \mathrm{CaCo}_{3}(\mathrm{~S})$

Study of effect of microbial cement on resistance of soil aggregate; have been conducted by various researchers [3]. Cementation effect due biological solutions to samples of sand through Undrained Triaxial test to measure the shear strength and permeability tests to determine soil permeability is investigated. It is observed that the process of calcite deposits lead to increasing the granular soil sample resistance (Figure 1).

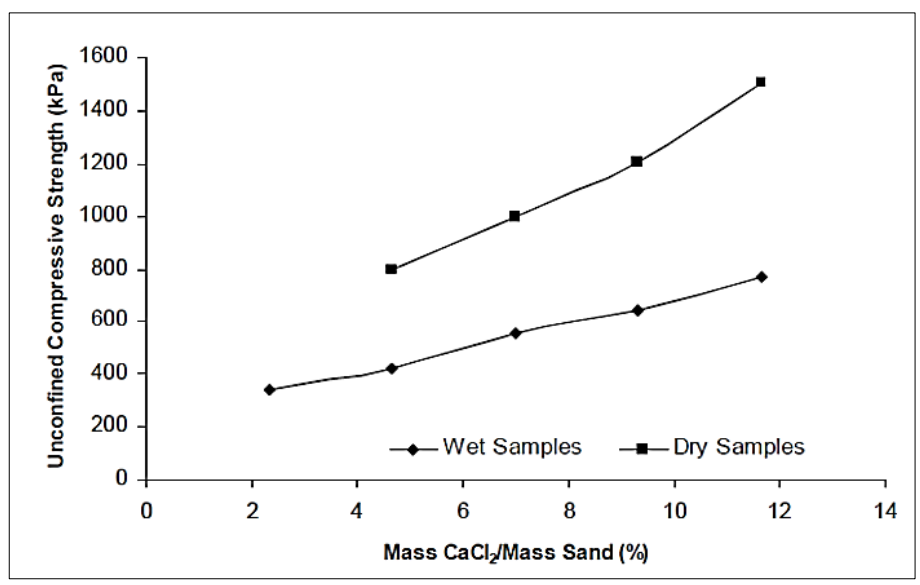

Figure 1. Sand samples uniaxial compressive strength improvement with different percentages of calcite sediment [1].

Thin crust and dense with a thickness of about $1 \mathrm{~mm}$ was formed on the surface of the improved sand. Scanning Electron Microscopy(SEM) showed that the formation of crystals $\mathrm{CaCo}_{3}$ is not within the pores of the sand, but directly is on the surface of the sand grain (Figure 2).
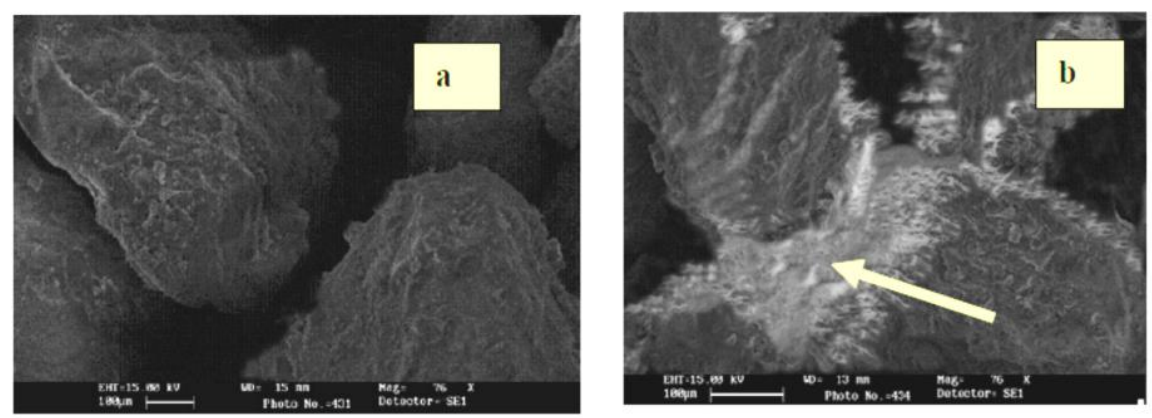

Figure 2. Microscopic image of calcite precipitation in granular soil pores [1].

These results corresponded with the studies about reduction the permeability of granular soil by adding microbial cement [4]. The study presented in the mentiones reference has shown that the use of biological cements can be used to build aquaculture ponds or tank in the sand. In Figure 3, the image of calcite deposits formation can be seen on aggregate surface.

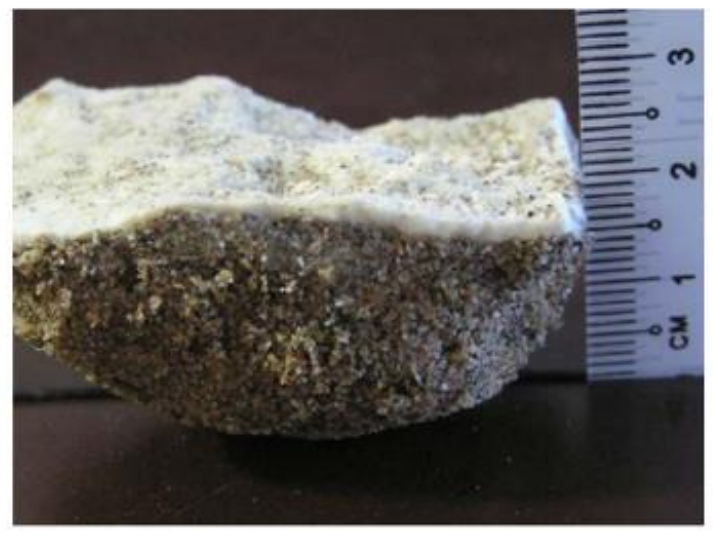

Figure 3. The crust was formed on the surface of granular materials [4].

Rong et al. (2012) found a high impact for the injection of microbes in soil samples on the amount of improvement 
the various parts of samples [2]. Since the injection direction was from top to bottom, the density of upper part is more than the lower one and specimen fracture location in uniaxial test was in the lower part of the specimen. The effect of direction and method of injection of microbes cement makers in Hushmand (2014) studies have been investigated [5]. In this study, for uniform and optimized injection, injection from below method, using schematic algorithm presented in Figure 4 is recommended and this method has been used in the present studies.

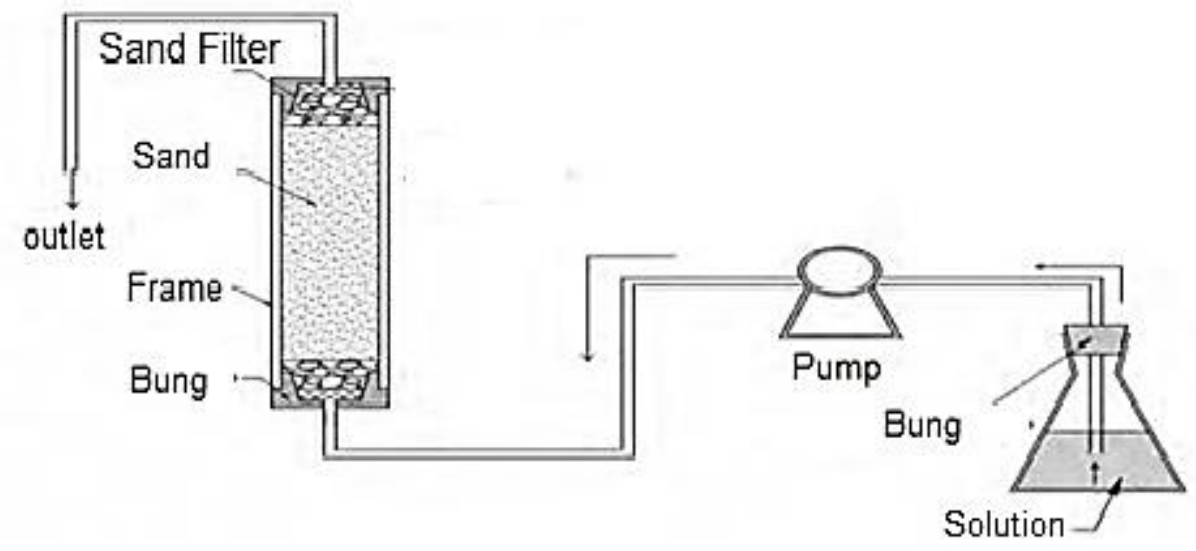

Figure 4. Illustration of the method of injection from bottom [5].

Cabalar et al. (2016) presented the triaxial testing to observe the behaviour at small strains of sand matrix in which biocementation processes were employed. Results indicate that at small strain levels the observed stiffness-strain behaviour of biocemented sand specimens appeared to be significantly high for all three treatment levels. The response of biocemented sands was found to be similar to that of calcite and lime cemented specimens, which represent conventional cementing agents [6]. Mujah et al. (2016) studied the performance of biocemented uniform silica sand ( $0.425 \mathrm{~mm}$ in diameter) under extreme environmental conditions including low, ambient and high surficial temperatures; different soil pH; and two freeze-thaw (FT) cycles conditions [7]. The unconfined compressive strength (UCS) results indicated that soil biocementation is more effective at the ambient temperature and neutral soil pH. Moreover, the results also demonstrated that the biocemented sand was able to withstand up to 10 FT cycles.

The ability of the bio-grouting mechanism to improve engineering properties (compressive strength) of stone/sand columns and the onset of precipitation of calcium carbonate crystals within the pore spaces of granular soils investigated by Mahawish et al. (2017). In this investigation, coarse sand is treated by light, moderate and heavy biochemical treatments using the bio-grouting method. The unconfined compressive strength (UCS) increased with the increase in the amount of deposited calcium carbonate, and the maximum UCS $(5500 \mathrm{kPa})$ was achieved with around $12 \%$ calcium carbonate precipitation [8].

Cheng et al., (2017) proposed an approach for applying biocementation in situ, by combining the surface percolation of nutrients and cementation solution (urea/CaCl2) with in situ cultivation of indigenous soil urease positive microorganisms under non-sterile conditions. Results showed that the in situ cultivated urease activity may produce non-clogging cementation over the entire 1000-mm columns, with unconfined compressive strength varying between $850-1560 \mathrm{kPa}$ (for coarse sand) and 150-700 kPa (for fine sand), after 10 subsequent applications of cementation solution [9]. Two sets of experiments are completed using soil samples obtained from different depths to evaluate the feasibility of stimulating native ureolytic microorganisms for MICP at depths relevant to geotechnical applications (Gomez et al., 2018). Following 14 cementation treatments, soil columns achieved final Vs values as high as $1,020 \mathrm{~m} / \mathrm{s}$ and unconfined compressive strengths as high as $1.9 \mathrm{MPa}$. The results of this study suggest that native ureolytic microorganisms may be successfully stimulated in natural soil deposits to induce calcite precipitation at treatment depths up to $12 \mathrm{~m}$ for geotechnical ground improvement [10].

\section{2-Materials and Methods}

\section{2-1- Microbial Solution Selection}

For crystal limestone microbial sediment hydrolysis of urea micro-organisms is required, that secretion most amount of the urease enzyme and in addition to be non-pathogenic and available. Therefore, a level called Sporosarsina Pasteurii that is part of non-pathogenic microorganisms, and splash most amount of urease was prepared.

\section{2-2- Medium for Microorganisms Growth}

Medium brain heart broth No. 1.10493.0500 was used. To grow the 37 gr of the above mentioned microorganisms it dissolved in the $1000 \mathrm{ml}$ distilled water then for $15 \mathrm{~min}$ at temperature $120^{\circ} \mathrm{C}$ put on at autoclave to sterilize, and then 
add the intended level to extra medium prepared. To reproduction and growth of bacteria, the medium containing the bacteria, placed inside incubator at $37^{\circ} \mathrm{C}$ for 48 hours Figure 5 and 6 show the described sequences and used units.

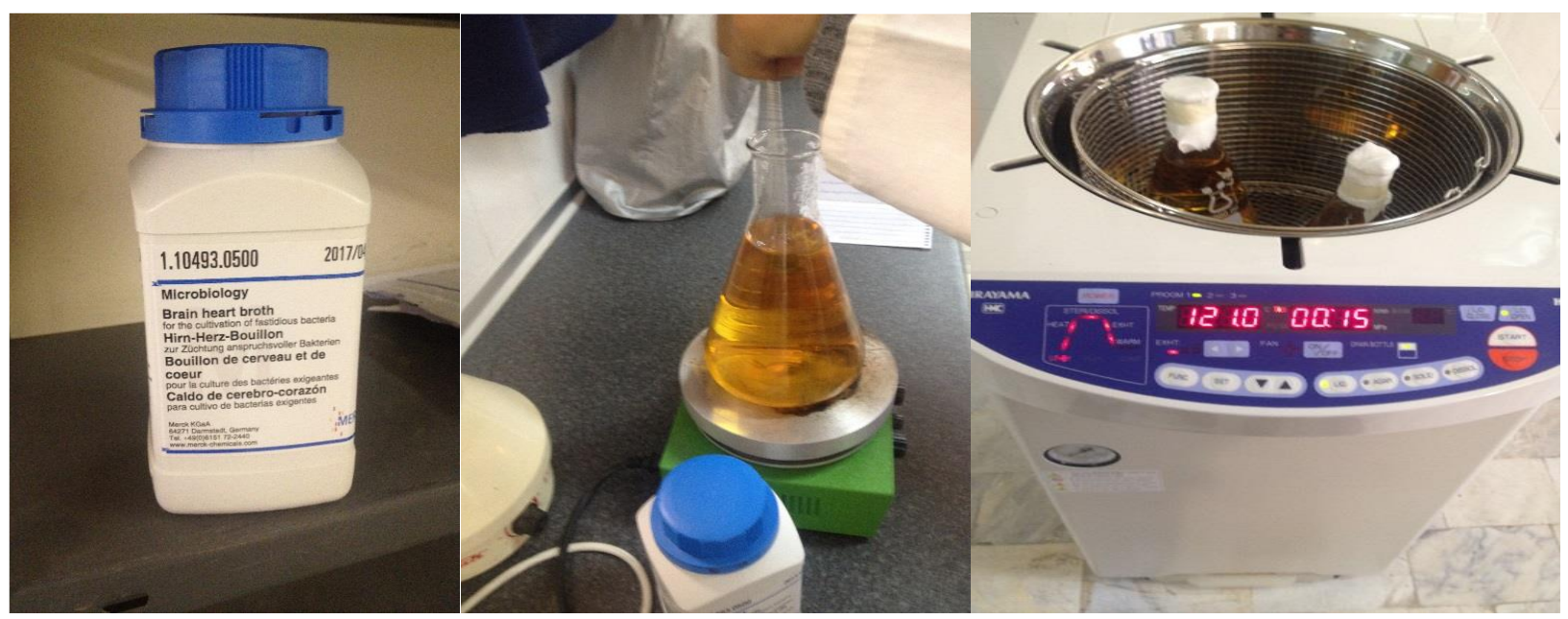

Figure 5. Stages of making and sterilize the medium of Brain Heart Broth.

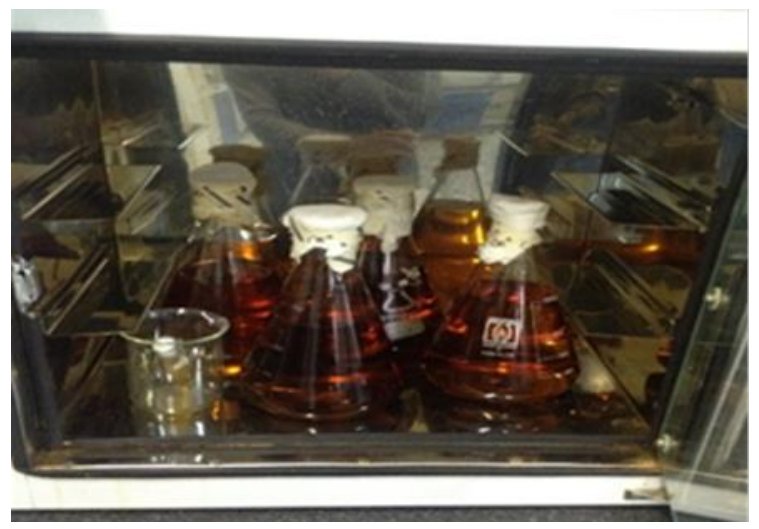

(a)

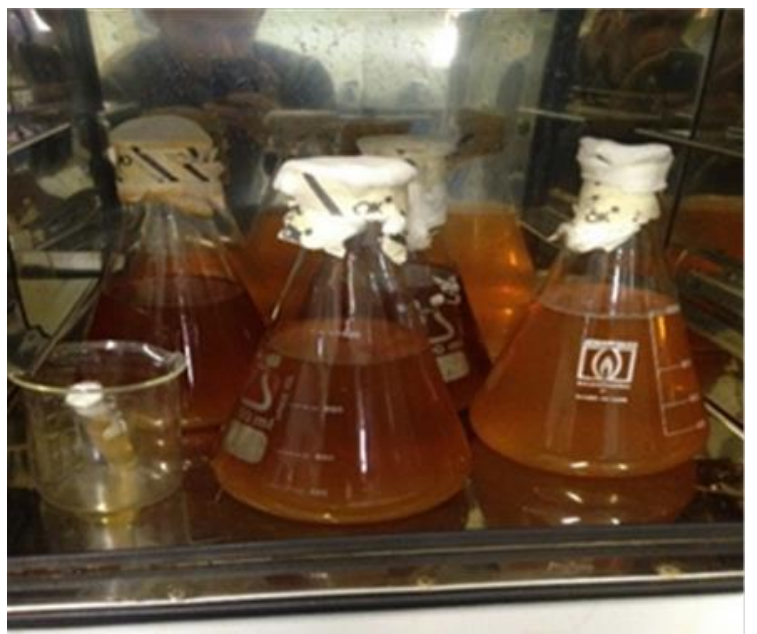

(b)

Figure 6. Adding the level of bacteria to medium and putting in an incubator, (a) Putting the medium containing the bacteria in the incubator, (b) The reproduction of bacteria after 48 hours.

\section{2-3- Identification Method}

The gram stain was used to see the microbe's appearance by microscope and in order to control the probability of the pollution of medium. Procedure of gram stain is as follows:

- Preparation of the bacteria on the slide and stabilize it after drying with heat. 
- Stained with crystal violet for 30 seconds until the color penetrate the cell walls of microbes.

- Microbial layer covering with Gram.

- Discoloring of sample by sweep for 10 to 20 Seconds.

- Painting the sample with fusion for 30 Seconds.

In Figure 7, image of resulting gram stain for bacteria cultured under microscope is shown.

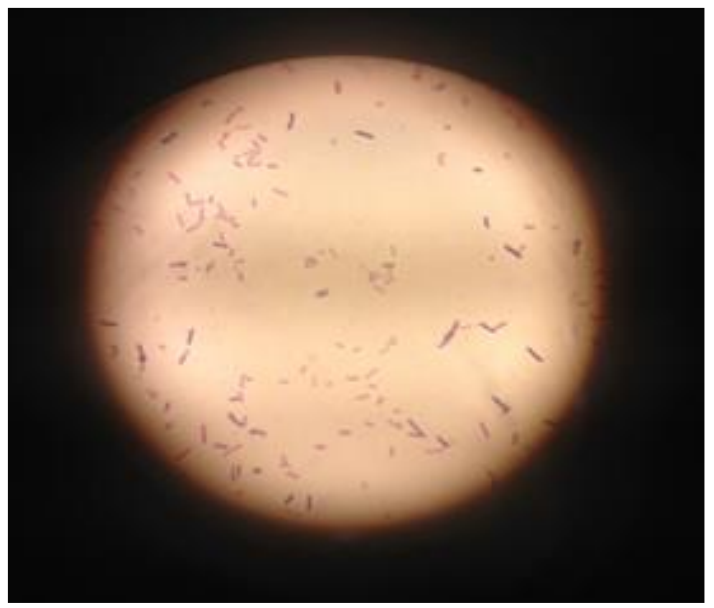

Figure 7. Bacteria Sporosarsina Pasteurii under a light microscope with 100 times enlargement.

\section{2-4- Soil Characterization}

The used soil in this study was Silty Sand of the industrial town of Garmsar. The grain size distribution of the soil which is determined based on ASTM D 6913 [11], is illustrated in Figure (8).

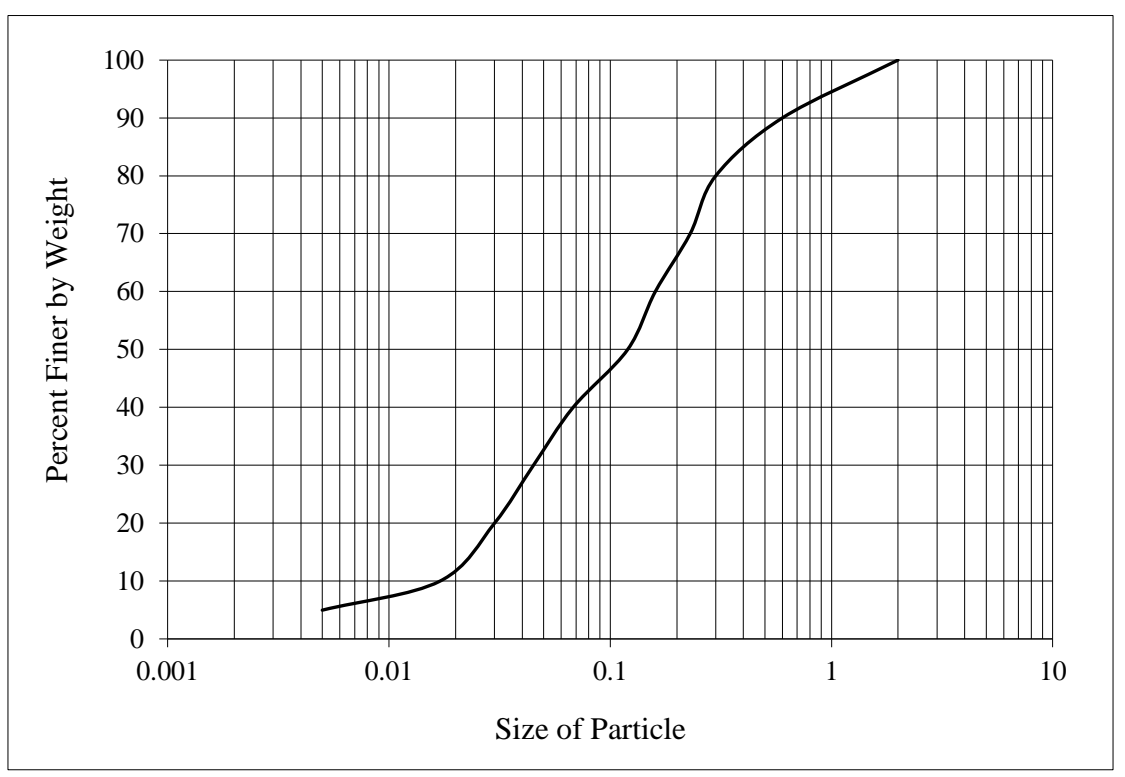

Figure 8. Particle-Size Distribution (Gradation) of the examined Silty Sand.

The grading characteristics and Aterberg Limits of the soil are presented in Table 1.

Table 1. Specifications of the evaluated Silty Sand (ASTM, D4318 [12]).

\begin{tabular}{ccclc}
\hline $\mathbf{D}_{\mathbf{1 0}}(\mathbf{m m})$ & $\mathbf{D}_{\mathbf{3 0}}(\mathbf{m m})$ & $\mathbf{D}_{\mathbf{6 0}}(\mathbf{m m})$ & Liquid Limit $(\mathbf{L L})$ & Plastic Limit $(\mathbf{P L})$ \\
\hline 0.017 & 0.045 & 0.16 & Indeterminable & NP \\
\hline
\end{tabular}

In Table 2 the chemical properties of soil material in the natural conditions are provided. 
Table 2. Chemical properties of the soil in the natural condition (ASTM C25 [13]).

\begin{tabular}{ccccc}
\hline $\begin{array}{c}\text { Percentage of } \\
\left(\mathrm{Al}_{\mathbf{2}} \mathrm{O}_{3}+\mathrm{Fe}_{2} \mathrm{O}_{3}\right)\end{array}$ & $\begin{array}{c}\text { Percentage of } \\
\mathrm{SiO}_{2}\end{array}$ & $\begin{array}{c}\text { Percentage of } \\
\mathbf{C a C o 3}\end{array}$ & $\begin{array}{c}\text { Salt } \\
\text { Percentage }\end{array}$ & $\begin{array}{c}\text { Plaster } \\
\text { Percentage CaSo4 }\end{array}$ \\
\hline 3.46 & 37.04 & 37.29 & 0.02 & 25.79 \\
\hline
\end{tabular}

3-

\section{Tests Results}

\section{3-1- Uniaxial Compression Test}

Uniaxial compressive tests are commonly used in order to determine the compressive strength of cohesive soil. This is used test on cohesive soils such as saturated clays or cemented soils which are able to hold their inherent resistance after the removal of restrictive pressure. The use of this test in dry soils or layered materials or slit, silt and sand have no useful results. In this test the samples placed under vertical load, which is gradually increased until failure occurs.

\section{3-1-1- Samples Preparation}

Since in this study uniaxial testing, was considered as a criterion measure of soil resistance, column with the same geometric characteristics of uniaxial testing was used as a laboratory pilot. Bacterial suspension was added to the sand column and the samples were completely saturated by shaking and vibrating table. It was first tried not limited compressive strength tests on the natural silty sand soil used in this study (without adding solution). Because of the lack of cohesion between soil particles, samples were disrupted during the exit from the mold, that it was not possible to perform uniaxial testing as it could be expected (Figure 9).

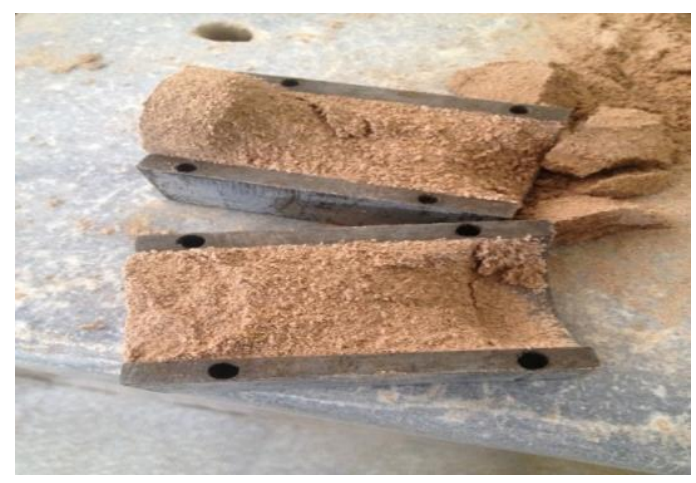

Figure 9. Failure of the prepared samples of granular aggregates before improvement with microbial cement.

\section{4- Tests Results}

\section{4-1- Variation of the Uniaxial Strength}

Uniaxial compressive strength tests are done on samples containing bacteria suspension, after 23, 61, and 71 days of adding suspension. The charts of uniaxial strength of different samples are shown in Figures 10 to 12.

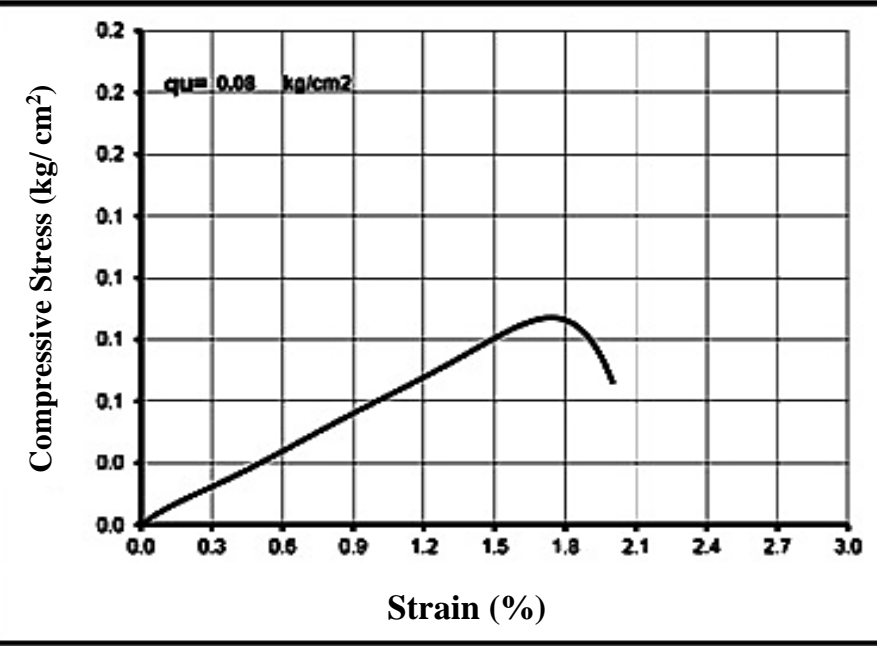

Figure 10. The uniaxial compressive strength of the first specimen (after 23 days of adding of bacteria). 


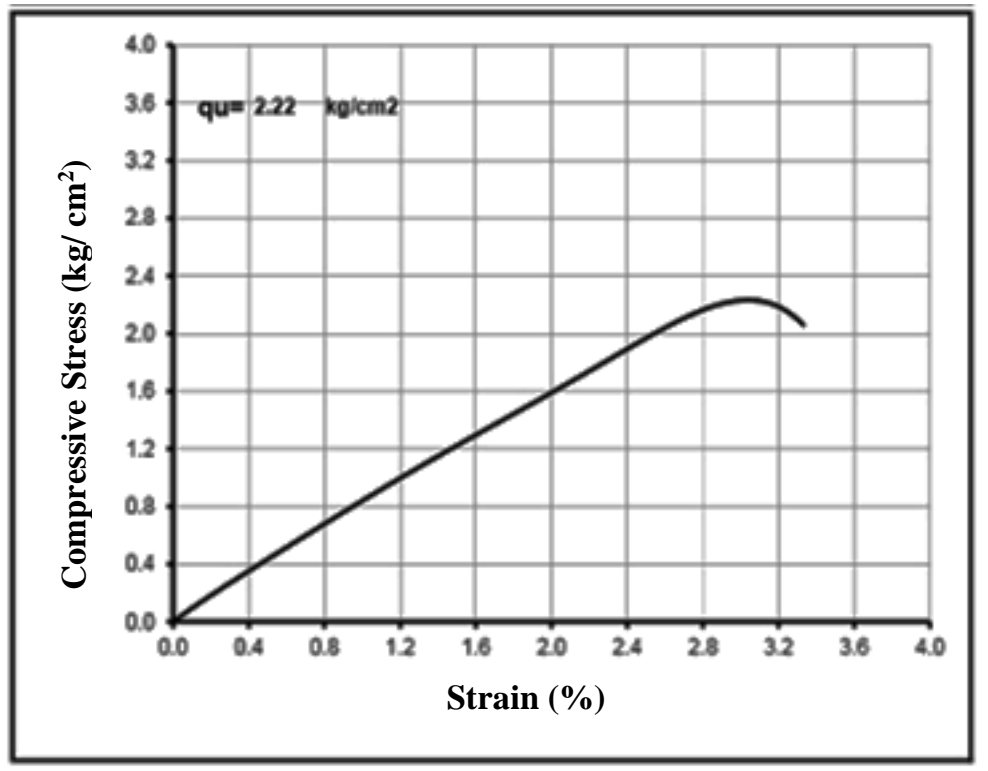

Figure 11. The uniaxial compressive strength of the first specimen (after 23 days of adding of bacteria).

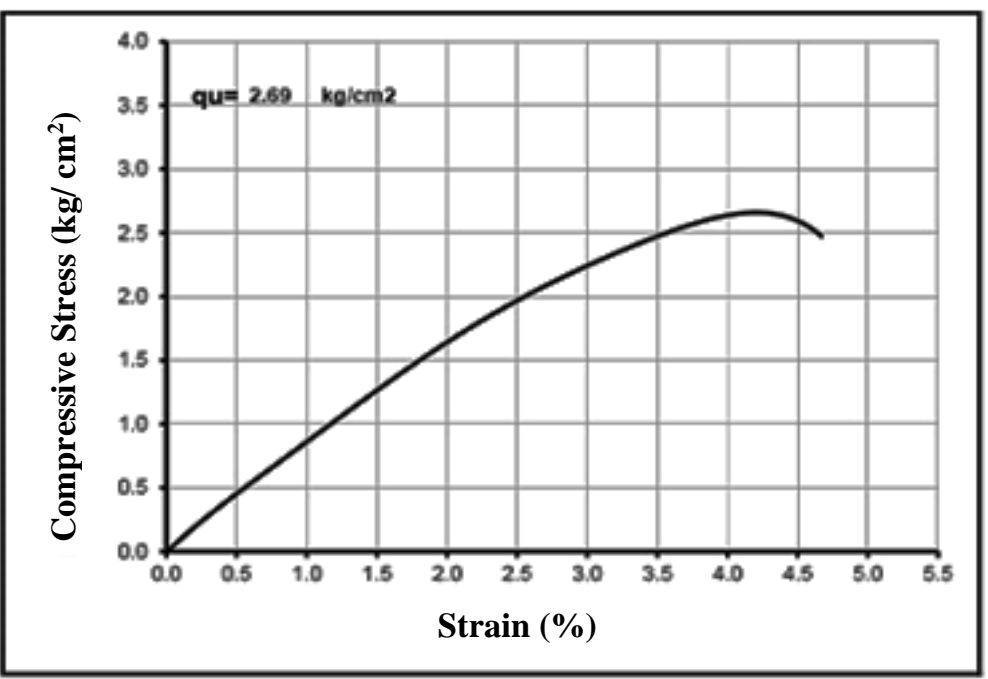

Figure 12. The uniaxial compressive strength of the first specimen (after 71 days of adding of bacteria).

In Figure 13 uniaxial resistance changes of samples with time is provided. This graph which shows the linear increase in the compressive strength with time has agreement with the results of previous studies of Ivanov and Chu (2007).

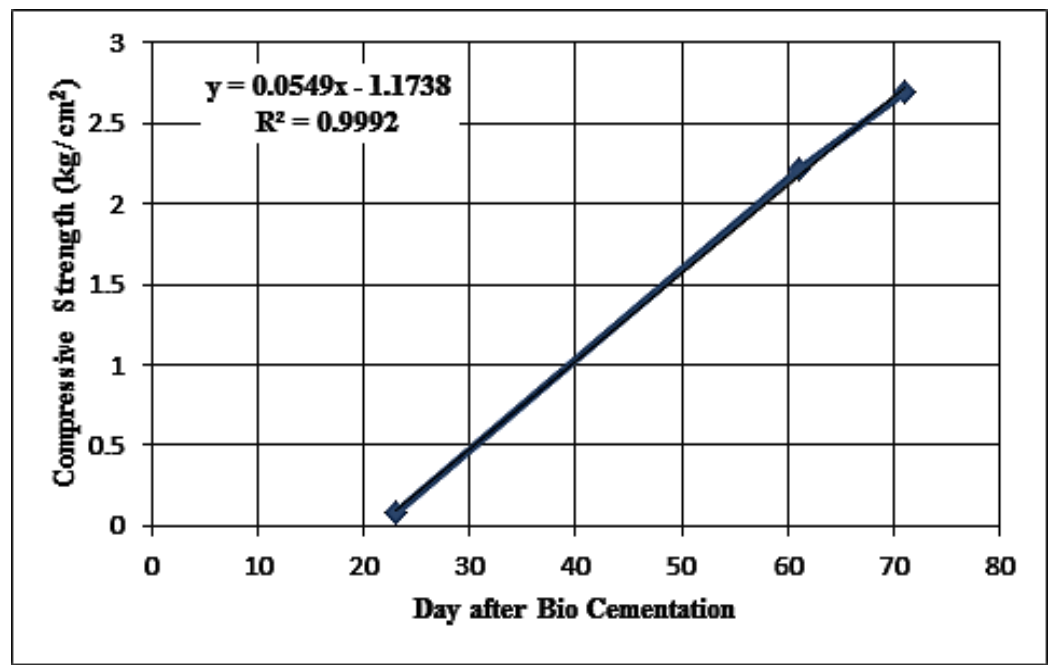

Figure 13. Variation of the uniaxial strength with time as a result of increasing the concentration of precipitated calcium carbonate. 
with respect to the results of uniaxial test provided in the form of Figure 10 to 13 it observed that ratio of second sample strength compared with the first one is about 28 times and this ratio for the third sample in comparison to the first one is about 34 times. But the ratio of compressive strength of third sample in comparison to the second one is 1.2 times. It is worth noting for natural soil sample without improvement (Figure 9) value of compressive strength was practically zero. But by Bacterial Cementation the amount of the soil resistance reached to the value of $2.7 \mathrm{~kg} / \mathrm{cm}^{2}$.

\section{4-2- Variation of the Stiffness}

Considering the slope of the samples stress-strain graphs, in Figure 14 samples tangent stiffness values are compared. As could be seen, the value of stiffness changes over time after about 23 to 61 days became sharp, but after that, with compatibility with the strength variation, the trend of rising in stiffness has been reduced.

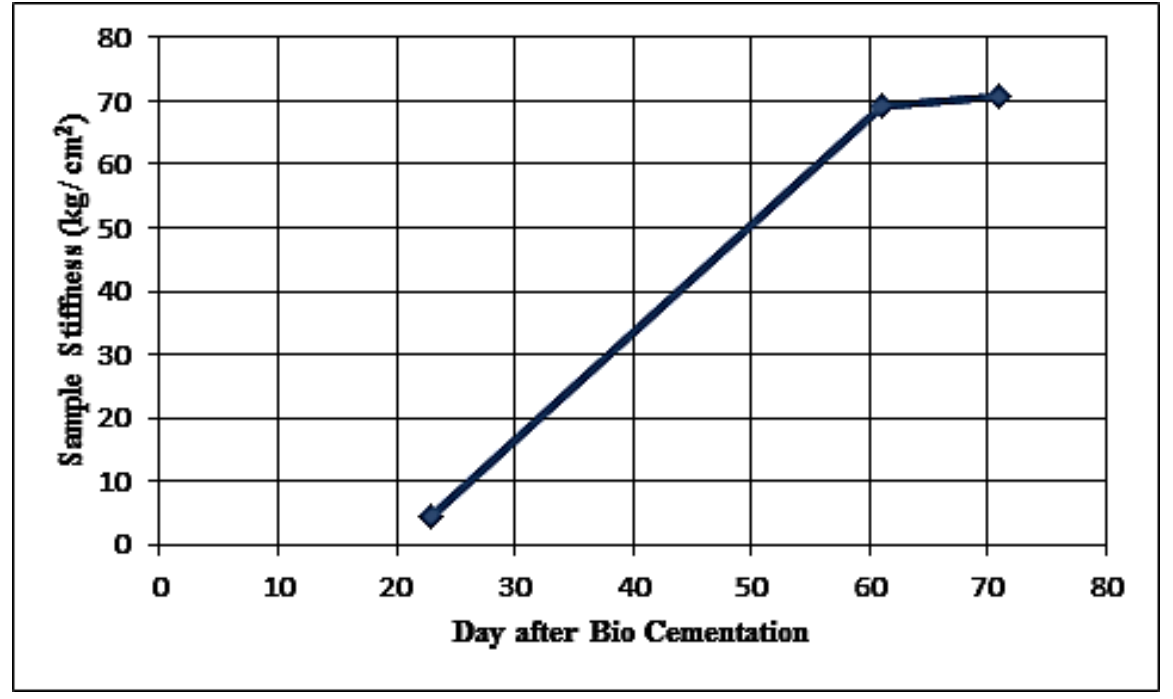

Figure 14. Samples stiffness variations improved with bacterial cementation.

\section{4-3- The Chemical Properties of Samples}

In Table 3, the chemical properties of sample No. 2 (after 61 days improvement) compared with the natural soil characteristics.

Table 3. Chemical properties of the soil, before and after microbial cementation (ASTM C25).

\begin{tabular}{cccccc}
\hline Sample Type & $\begin{array}{c}\text { Plaster Percentage } \\
\left(\mathbf{C a S O}_{4}\right)\end{array}$ & $\begin{array}{c}\text { Salt } \\
\text { Percentage }\end{array}$ & $\begin{array}{c}\text { Percentage of } \\
\left(\mathbf{C a C o}_{3}\right)\end{array}$ & $\begin{array}{c}\text { Percentage of } \\
\left(\mathbf{S i O}_{2}\right)\end{array}$ & $\begin{array}{c}\text { Percentage } \\
\mathbf{o f}\left(\mathbf{A l}_{2} \mathbf{O}_{3}+\mathbf{F e}_{2} \mathbf{O}\right)\end{array}$ \\
\hline Natural & 25.79 & 0.02 & 37.29 & 37.04 & 3.46 \\
After 61 Days Improved With Bacteria & 39.15 & 0.02 & 41.71 & 31.04 & 3.58 \\
\hline
\end{tabular}

The changes are compared in Figure 15. It could be concluded while the increase of $\mathrm{CaCO}_{3}$ and $\mathrm{CaSo}_{4}$ and decrease of the $\mathrm{SiO}_{2}$, the density of Salt, Iron Oxide and Aluminium of the samples remained relatively constant.

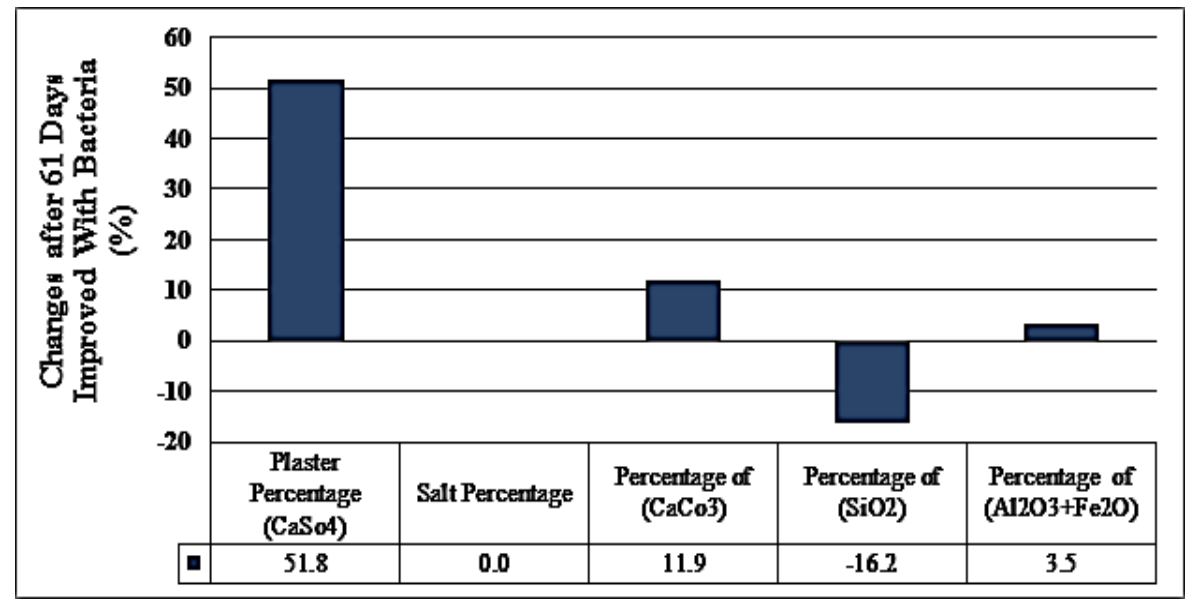

Figure 15. Percentage of the Chemical properties changes after microbial cementation. 


\section{5- Conclusions}

According to the results presented in this article, results can be summarized as follows:

- Bio-Cementation method in addition to increasing uniaxial compressive strength causes to increase the Stiffness of the soil granular samples.

- Bio-Cementation method while increasing the compressive strength and stiffness has no effect on the density of iron oxide and aluminium, and also salt content of the soil. But it leads to the precipitation calcium carbonate and chalk in the pores of the granular soil and this results the mentioned resistance increase of the granular soil.

- By using sand column injection and unlimited compressive tests, the necessary variables parameters (for optimum condition) such as compressive strength, durability, essential dosage, amount of mass uniformity improvement can be derived.

- Bio-Cementation method compared with the conventional injection method has many features such as lower cost, less pressure, more radius of influence, in accordance with the environmental conditions that would justify the use of this method.

\section{6- Compliance with Ethical Standards}

Regarding the tests program which has been done by studying the effect of the sedimentation of calcium carbonate as a producer of Urease for improvement of granular soil, no potential conflicts of interest have been occurred.

Also this article does not contain any studies with human participants or animals performed by any of the authors. Regarding the informed consent, it was obtained from all individual participants included in the study

\section{7- References}

[1] Ivanov I., Chu J., 2007, Applications of microorganisms to geotechnical engineering for bioclogging and biocementation of soil in situ, Rev. Environ. Sci. Biotechnol. DOI 10.1007/S11157-007-9126-3, DOI: https://doi.org/10.1007/s11157-007-9126-3.

[2] Rong H., Qian C-X., Li L-Z., 2012, Study on microstructure and properties of sandstone cemented by microbe cement, Construction and Building Materials 36 (2012) 687-694, DOI: https://doi.org/10.1016/j.conbuildmat.2012.06.063.

[3] Ivanov V., Chu J., Jia H., Chenghong G., Rezaei Nejad S., And Naeimi M., 2009, Bioclogging and biocementation of soil in geotechnical engineering, 8th International Congress On Civil Engineering, Shiraz, Iran.

[4] Stabnikov V., Naeimi M., Ivanov I., Chu J., 2011, Formation of water-impermeable crust on sand surface using bio cement, Concrete Research 41 (2011), DOI: https://doi.org/10.1016/j.cemconres.2011.06.017.

[5] Hushmand A., Emami A., Abraham S., 2014, the effect of the injection on the compression strength of not limited biological soil improvement and the amount of calcium carbonate in the soil, in Persian, The 7th national congress of civil engineering, Shaheed Nikbakht Engineering College, Zahedan, 17 and 18 may 2014.

[6] Cabalar A. F., Karabash Z., Erkmen O., 2016, Stiffness of a biocemented sand at small strains, European Journal of Environmental and Civil Engineering, DOI: 10.1080/19648189.2016.1248791.

[7] Mujah D., Shahin M., Cheng L., 2016, Performance of biocemented sand under various environmental conditions, XVIII Brazilian Conference on Soil Mechanics and Geotechnical Engineering The Sustainable Future of Brazil goes through our Minas COBRAMSEG 2016 - 19-22 October, Belo Horizonte, Minas Gerais, Brazil @ ABMS, 2016.

[8] Mahawish A., Bouazza A., Gates A. P., 2017, Microstruture of biocemented coarse sand, DFI-PFSF 2017 Conference, Melbourne.

[9] Cheng L., Shahin M. A., Cord-Ruwisch R., 2017, Surface Percolation for Soil Improvement by Biocementation Utilizing In Situ Enriched Indigenous Aerobic and Anaerobic Ureolytic Soil Microorganisms, Volume 34, 2017 - Issue 6, pages 546 to 556 , DOI: 10.1080/01490451.2016.1232766.

[10] Gomez M. G., Graddy C. M. R.; DeJong J. T., Nelson D. C. , 2018, Stimulation of Native Microorganisms for Biocementation in Samples Recovered from Field-Scale Treatment Depths, Journal of Geotechnical and Geoenvironmental Engineering, Volume 144 Issue 1 - January 2018, DOI: 10.1061/(ASCE)GT.1943-5606.0001804.

[11] ASTM D 6913, 2009, Standard Test Methods for Particle-Size Distribution (Gradation) of Soils Using Sieve Analysis, DOI: 10.1520/D6913_D6913M-17.

[12] ASTM D 4318, 2010, Standard Test Methods for Liquid Limit, Plastic Limit, and Plasticity Index of Soils, DOI: 10.1520/D4318$17 \mathrm{E} 01$.

[13] ASTM C 25, 1999, Standard Test Methods for Chemical Analysis of Limestone, Quicklime, and Hydrated Lime, DOI: $10.1520 /$ C0025-99. 